\title{
Temozolomide Regimen
}

National Cancer Institute

\section{Source}

National Cancer Institute. Temozolomide Regimen. NCI Thesaurus. Code C160122.

A chemotherapy regimen consisting of temozolomide that may be used in the treatment of soft tissue and uterine sarcoma, cutaneous melanoma, pancreatic neuroendocrine tumors (NETs) and small cell lung cancer (SCLC). 